\title{
Principios físicoquímicos de los colorantes utilizados en microbiología
}

\author{
Physicochemical Principles of dyes used In Microbiology
}

Lucía Constanza Corrales Ramírez ${ }^{1}$, Liliana Caycedo Lozano ${ }^{2}$

\section{Resumen}

La utilización de los colorantes en los procesos de identificación en microbiología se fundamenta en las propiedades fisicoquímicas de estas sustancias. En el campo de la física, la óptica explica cómo todos los objetos son observables dependiendo de las longitudes de onda que se absorben y se transmiten dentro del denominado "espectro visible". Dichas transiciones se deben, a su vez, a los compuestos químicos y a los movimientos electrónicos dentro de los átomos. Así mismo, cuando interacciona un colorante con una célula o un tejido, ocurren reacciones que dependen de grupos químicos funcionales denominados cromóforos y auxocromos.

Dependiendo de los compuestos químicos que los constituyen, los colorantes pueden ser ácidos, básicos o neutros y esta connotación se debe a la parte activa del colorante y a la reacción que ocasiona sobre las células microbianas.

De otra parte, las tinciones en microbiología pueden ser simples o diferenciales, dependiendo si toda la muestra se tiñe de uno o más colorantes. En el primer caso se encuentra el ejemplo de la coloración con azul de lactofenol y en el segundo, la coloración de Gram.

En el presente artículo se reseñan las principales coloraciones utilizadas en microbiología y se explican los fundamentos físicos y químicos de dichos procesos.

Palabras claves: colorante, espectro visible, grupos funcionales, microbiología.

\footnotetext{
1. Docente, Programa Bacteriología y Laboratorio Clínico. Universidad Colegio mayor de Cundinamarca

Número de certificación CvLac 000048264120121119123

ORCID: http://orcid.org/0000-0002-2398-348X

2. Docente, Programa de Ciencias Básicas. Universidad Colegio mayor de Cundinamarca

Número de certificación CvLac 0000660221

ORCID: http://orcid.org/0000-0002-9274-3148.

Correspondencia: Icorrales@unicolmayor.edu.co
} 


\section{Abstract}

The use of dyes in the identification processes in microbiology is based on the physicochemical properties of these substances. In the field of physics, optics explains how all objects are observable depending on the wavelengths that are absorbed and transmitted within the so-called "visible spectrum". These transitions are, in turn, due to chemical compounds and the electronic movements within atoms. Likewise, when a dye interacts with a cell or tissue, reactions occur that depend on functional chemical groups called chromophores and auxochromes.

Depending on the chemical compounds that constitute them, the dyes can be acidic, basic or neutral and this connotation is due to the active part of the dye and the reaction it causes on the microbial cells.

On the other hand, stains in microbiology can be simple or differential, depending on whether the entire sample is stained with one or more dyes. In the first case is the example of the lactophenol blue staining and in the second, the Gram staining.

This article describes the main colorations used in microbiology and explains the physical and chemical foundations of these processes.

Keywords: Dye, Visible Spectrum, Functional Groups, Microbiology.

\section{Introducción}

Las coloraciones o tinciones en microbiología se constituyen en el primer paso del proceso del análisis en el laboratorio para la identificación presuntiva de agentes infecciosos.

En el análisis microbiológico, el microscopio es la principal herramienta que se utiliza de forma rutinaria, por cuanto suministra información sobre la morfología, asociación y afinidad por la o las coloraciones para la identificación presuntiva o definitiva de los microorganismos.

Desde hace más de un siglo, la microscopía ha ayudado a resolver problemas de etiología microbiana (1). Hay una gran variedad de tinciones que se han ido desarrollando para la detección de los diferentes agentes infecciosos como bacterias, parásitos y hongos. La tinción de Gram se considera básica en la valoración inicial de muestras 
para análisis bacteriológico, mientras que tinciones como las de Wright son utilizadas para el diagnóstico de enfermedades relacionadas con parasitos (2). Existen otras técnicas tintoriales específicas de gran utilidad, como la tinción de Ziehl-Neelsen, que se utiliza para el diagnóstico de bacilos ácido alcohol resistentes, o la tinción de azul de lactofenol, que conserva y tiñe los componentes estructurales de los hongos. En general, las diferentes tinciones que se utilizan en el laboratorio de microbiología, son técnicas sencillas, rápidas y que aportan información fundamental para el diagnóstico y procedimiento terapéutico oportuno de múltiples patologías de origen infeccioso (3).

Los colorantes son sustancias que tienen la capacidad de teñir células, estructuras o tejidos; y de acuerdo con su origen, permiten hacer visibles los objetos microscópicos y transparentes, conocer su forma y tamaño, así como sus estructuras internas y externas. Los colorantes hacen parte de reacciones químicas específicas y de acuerdo con su origen, se pueden clasificar en naturales, aquellos que son extraídos de plantas o animales, y artificiales, los que se extraen de minerales y son procesados en el laboratorio. En cuanto a su estructura química los colorantes están constituidos por un grupo funcional cromóforo y un auxócromo (4).

En un colorante, el cromóforo es un grupo funcional que cuenta con una alta densidad electrónica y por lo tanto se pueden clasificar de la siguiente manera:
- Dobles y triples enlaces carbono-carbono

- Anillos aromáticos

- Grupos carbonilos, imino, diazo y nitro

- Estructuras que presenten enlaces entre el carbono y átomos con pares de electrones libres.

Por su parte, los auxocromos, son sustituyentes del cromóforo y alteran los valores de las longitudes de onda en las que se presentan las absorciones de la luz. Generalmente, los auxocromos son grupos mucho más sencillos que los cromóforos, como es el caso de grupos metilo (-CH3), halógenos $(-\mathrm{X})$, hidroxilos $(-\mathrm{OH})$, y amino (-NH2).

Dependiendo de la sustitución en el cromóforo y el sustituyente o auxocromo, los efectos que se logran en la molécula del colorante se han clasificado de acuerdo al desplazamiento de la banda de absorción en el espectro.

Si el auxocromo causa una absorción del cromóforo hacia longitudes de onda mayores se denomina batocrómico.

Si el auxocromo causa una absorción del cromóforo hacia longitudes de onda menores se denomina hipsocrómico (5).

\section{Fundamento fisicoquímico de las coloraciones}

De acuerdo con lo anterior, un colorante es un compuesto orgánico que al aplicarlo a un sustrato (orgánico o inorgánico) le altera 
la propiedad física del color atendiendo a la modificación en las zonas de absorción del espectro visible.

\section{- Color y colorantes}

De acuerdo con Flores y cols.: “...la búsqueda de la esencia del color se pierde en la antigüedad..." (6). La anterior afirmación se centra en que a través de los tiempos, desde físicos hasta sicólogos, pasando por químicos y artistas, han definido el color desde sus propios intereses y lo han ligado a su campo de desempeńo. Todos hemos tratado de brindar una definición a un fenómeno físico/químico tan etéreo, pero a la vez tan perceptible que se conoce como "color" y que nos permite aproximarnos y hacer visible aquello que no nos es conocido.

En términos fisicoquímicos se puede definir el color a partir de las transiciones elec- trónicas que ocurren al interior de los átomos y que permiten simultáneamente dos fenómenos (la absorción y la emisión) de radiación en el espectro denominado visible $(400 \mathrm{~nm}$ a $700 \mathrm{~nm})$ que es perceptible por el ojo humano (6).

Así, las transiciones electrónicas de los átomos que constituyen una sustancia, permitirán la observación (color) de las ondas que no son absorbidas de toda la gama del espectro visible de energía por parte de los electrones.

La anterior definición para el color está asociada a una "sustancia" que absorbe y emite energía en el intervalo del espectro visible $(400 \mathrm{~nm}$ a $700 \mathrm{~nm})$ y los colores corresponden al único rango que no se absorbe y que es visible al ojo (4).

Tabla 1. Rangos de longitudes de onda para los diferentes colores.

\begin{tabular}{|c|c|c|c|}
\hline $\begin{array}{l}\text { Rango de longitud de onda } \\
\text { absorbida }(\mathrm{nm})\end{array}$ & $\begin{array}{c}\text { Rango de longitud de onda } \\
\text { emitido }(\mathrm{nm})\end{array}$ & Color percibido & Apreciación del color \\
\hline$-470-500$ & $-700-620$ & Rojo & \\
\hline$-430-470$ & $-620-592$ & Naranja & \\
\hline$-400-430$ & $-592-578$ & Amarillo & \\
\hline$-610-700$ & $-578-500$ & Verde & \\
\hline$-590-610$ & $-500-450$ & Azul & \\
\hline$-570-590$ & $-450-400$ & Violeta & \\
\hline
\end{tabular}


Si las transiciones electrónicas ocurren en intervalos por debajo de $400 \mathrm{~nm}$ corresponden a absorciones que se "observan" en el espectro infrarrojo, y no serán detectadas por el ojo como colores; así mismo, si las transiciones ocurren por encima de $700 \mathrm{~nm}$ corresponden a absorciones que se "observan" en el espectro ultravioleta y tampoco serán detectadas por el ojo como colores.

La óptica ha permitido establecer que los objetos son visibles dependiendo de la luz que sobre ellos incida y de acuerdo a lo anterior el color que tome dicho objeto depende de la radiación que el mismo emita (7).

En este sentido, si el objeto es verde toda la luz que incide sobre él se descompone y transmite al ojo solo la longitud correspondiente al rango entre 500 y $578 \mathrm{~nm}$, el resto lo absorbe gracias a las transiciones electrónicas que ocurren en los niveles de energía de los átomos que lo componen.

Como se mencionó anteriormente, los responsables de los colores en los compuestos son los cromóforos y sus colores se intensifican o modifican por la presencia de los auxocromos.

La alta densidad electrónica presente en algunos grupos funcionales explica por qué son considerados cromóforos por excelencia (5).

Figura 1. Grupo Azo.

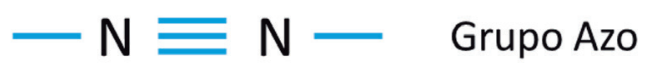

En el grupo AZO, cada átomo de nitrógeno posee 5 electrones de valencia de los cuales comparte 2 con el otro átomo de nitrógeno y uno queda disponible para enlazarse bien sea con un radical aromático o alifático. Esto quiere decir que el grupo funcional cuenta con alta densidad electrónica aportada por pares de electrones libres que no intervienen en los enlaces; y además, existen electrones en orbitales "p" que constituyen enlaces "pi" entre los dos átomos. Lo anterior facilita la movilidad de los electrones y las absorciones de energía que, como ya se estableció ocasionan el color (8). La presencia o no de este grupo ha permitido clasificar los colorantes en azoicos y no azoicos.

Figura 2. Grupo Nitro y grupo nitroso.

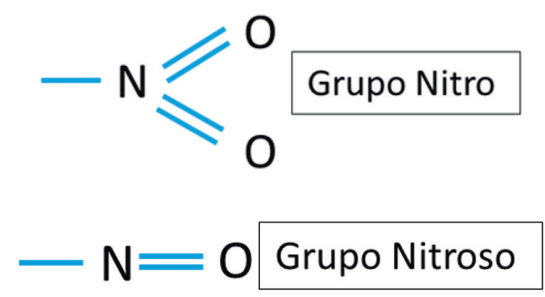

De otro lado, en los grupos NITRO y NITROSO, la configuración electrónica del nitrógeno en los grupos es: $1 s^{2} 2 s^{2} 2 \mathrm{p}^{3}$, y la configuración del oxígeno en éstos mismos grupos es: $1 s^{2} 2 s^{2} 2 p^{4}$.

En las asociaciones moleculares, entre el átomo de nitrógeno y el de oxígeno se conjugan altas densidades electrónicas de estos elementos electronegativos. Con el fin de alcanzar la estabilidad química, puede ocurrir que se presenten enlaces con uno o dos 
átomos de oxígeno en los que intervienen electrones procedentes de orbitales "p".

Una situación similar ocurre en los grupos funcionales "TIO" en los que se presentan enlaces covalentes entre el átomo de azufre y el de carbono e igualmente la densidad electrónica es muy alta alrededor de los núcleos de los átomos mencionados, presentando cada uno de los átomos las siguientes distribuciones electrónicas: carbono: $1 s^{2} 2 s^{2} 2 \mathrm{p}^{2}$ y azufre: $1 s^{2} 2 s^{2} 2 p^{6} 3 s^{2} 3 p^{4}$.

Figura 3. Grupo Tio.

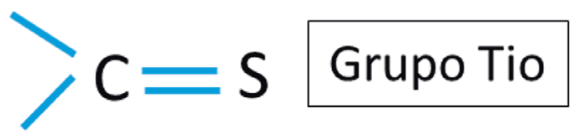

Un factor que aumenta la concentración de electrones en estos cromóforos está relacionado con que usualmente se encuentran asociados a anillos aromáticos que aportan electrones a las nubes electrónicas; y por ende, a las transiciones en los niveles atómicos, ocasionando alteraciones en el espectro visible, que como ya se anotó, originan el fenómeno del color.

Por su parte, las estructuras de los auxocromos corresponden a grupos menos complejos y con menores densidades electrónicas.

Tal es el caso de los grupos hidroxilo (-OH); metoxi $\left(-\mathrm{OCH}_{3}\right)$; amino $\left(-\mathrm{NH}_{2}\right)$ y los halógenos $(\mathrm{Cl}, \mathrm{I}, \mathrm{Br})$.

En general, cuanto mayor sea el número de dobles ligaduras conjugadas en un grupo funcional, mejor se comportará como cromóforo debido a que las transiciones electrónicas se facilitan en atención a la diferencia entre los niveles de energía. Así mismo, entre mayor número de enlaces conjugados haya en la molécula mayor es el rango de longitud de onda absorbida y mayor también la intensidad del color (9).

Siguiendo lo planteado por Magdalena “... un colorante es un tinte extraído de plantas o animales (de origen natural) o de minerales procesados en un laboratorio; mientras que un pigmento es una sustancia natural o artificial, que no es soluble en agua ni en aceite, que se usa para colorear, opacar o transparentar el color de un objeto" (10).

Teniendo en cuenta las estructuras químicas generales de los colorantes y la densidad electrónica que en ellos se presenta, la propiedad de teñir depende principalmente del carácter ácido o básico del grupo funcional (cromóforo) (11).

De acuerdo con lo anterior, la clasificación según la acidez de los colorantes es de especial importancia en el trabajo con dichos compuestos en el campo de la microbiología.

Colorantes neutros: se obtienen a partir de los precipitados provenientes de soluciones acuosas en las que se encuentran disueltos cromóforos con características ácidas y básicas $(8,10)$. El colorante se produce disolviendo el precipitado en alcohol, tal es el caso de la Giemsa. 
En la tinción de Giemsa, se combinan el carácter básico de los colorantes azul de metileno, Azure A y Azure B y el carácter ácido de la eosina, lo que ofrece un espectro amplio de colores dependiendo de los ajustes de $\mathrm{pH}$.

Colorantes básicos: la acción colorante está a cargo del catión, mientras que el anión no tiene esa propiedad. Un ejemplo es el azul de metileno (cloruro de metiltionina). El grupo amino (básico) es el grupo funcional activo en la molécula (12).

Figura 4. Cloruro de Metionina.

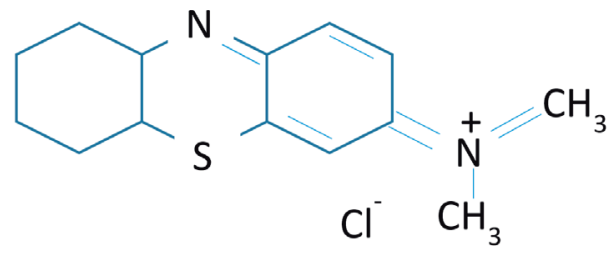

Cloruro de metionina

Colorantes ácidos: la sustancia colorante está a cargo del anión, mientras que el catión no tiene esa propiedad. Un ejemplo es la Eosina o Eosinato de sodio. El grupo carboxilo (ácido) es el grupo funcional activo en la molécula (12).

Figura 5. Eosinato.

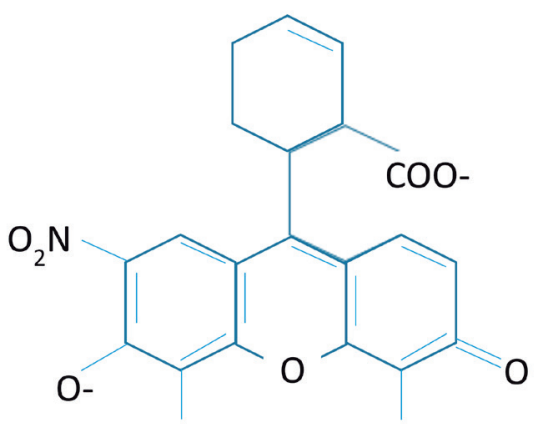

Eosinato
Al momento de la coloración, ocurre una combinación de procesos físicos y reacciones químicas: la solubilidad y las interacciones moleculares son claves para explicar el fenómeno de tinción (12).

\section{- Procesos Físicos}

$\mathrm{Al}$ contacto con el colorante ocurre un fenómeno de absorción, similar al que tiene lugar en las materias porosas, dicho compuesto penetra al interior del sustrato aprovechando los espacios intersticiales y la cohesión molecular, sin que ocurra enlace químico. Es un proceso que se explica similar a la solubilidad de una sustancia en otra (11).

\section{- Reacción Química}

Las células microbianas contienen compuestos entre los cuales se encuentran los ácidos nucleícos. Debido a la presencia de los grupos fosfato en dichos ácidos, se concentran en las moléculas cargas negativas, las cuales facilitan combinaciones con los colorantes de tipo básico catiónicos $(13,14)$.

De otra parte, los colorantes ácidos, aniónicos, no tińen la célula y por esto, se emplean como colorantes de contraste, como, por ejemplo: el azul de metileno o la eosina que no colorean al microorganismo, pero si el fondo del campo microscópico (14).

Las coloraciones pueden ser simples cuando toda la muestra se tińe del mismo color y se utiliza un sólo colorante: es el caso de 
azul de metileno de Löeffler o tinta china. De otra parte, la coloración diferencial ocurre cuando se visualiza más de un color porque se utiliza un colorante primario y otro de contraste. En algunos casos también se emplean mordientes y sustancias decolorantes, como en la coloración de Gram o Ziehl-Neelsen; o en coloraciones cuando se utilizan anticuerpos marcados con una molécula fluorescente para identificar estructuras celulares específicas, denominadas coloraciones inmunocitoquímicas $(12,15)$.

Algunas preparaciones biológicas requieren antes de su proceso de coloración, la fijación de las muestras, con el propósito de preservar la geometría estructural y química de las células que se desean visualizar, y esta fijación se puede realizar por métodos físicos o químicos.

Entre los procesos de fijación físicos se encuentran la desecación, calor seco, calor húmedo, ultrasonido y microondas; y en los de fijación químicos se encuentran procesos de oxidación en los que se utilizan compuestos que tienen la propiedad de comportarse como oxidantes, tales como el óxido crómico $\left(\mathrm{Cr}_{2} \mathrm{O}_{3}\right)$, ácido acético $\left(\mathrm{CH}_{3} \mathrm{COOH}\right)$, ácido pícrico $\left(\mathrm{C}_{6} \mathrm{H}_{2} \mathrm{OH}(-\right.$ $\left.\mathrm{NO}_{2}\right)_{3}$, acetona $\left(\mathrm{CH}_{3} \mathrm{COCH}_{3}\right)$, dicromato de potasio (K2Cr2O7) y reductores como aldehídos y alcoholes entre los que se encuentran: el formaldehído $\left(\mathrm{CH}_{2} \mathrm{O}\right)$, glutaraldehído $\left(\mathrm{OHC}\left(\mathrm{CH}_{2}\right)_{3} \mathrm{CHO}\right)$, etanol $\left(\mathrm{C}_{2} \mathrm{H}_{5} \mathrm{OH}\right)$, metanol $\left(\mathrm{CH}_{3} \mathrm{OH}\right)$ y paraldehído $\left(\mathrm{C}_{6} \mathrm{H}_{12} \mathrm{O}_{3}\right)(15)$.
El método de fijación más utilizado en microbiología es el físico, por medio del calor seco, que consiste en exponer directamente la lámina con la preparación a la llama del mechero. Este procedimiento detiene los procesos vitales de los microorganismos sin alterar sus estructuras. Parece sencillo, pero hay que tener en cuenta que la sobreexposición al calor, o la exposición en una zona incorrecta de la llama (zona fría, zona caliente y zona de fusión) incide en el efecto deseado; así, es muy común provocar alteraciones morfológicas y destrucción celular. El tiempo de preservación del extendido por este método es corto. De otro lado, los métodos químicos ofrecen mejores resultados para la fijación, ya que son líquidos-solventes con potencial alto de difusión intracelular y detienen procesos enzimáticos que provocan autolisis. Estos fijadores tienen la capacidad de interactuar con biomoléculas como proteínas, glicoproteínas, péptidoglicanos, lípidos, glicolípidos, lipoproteínas, pigmentos, ácidos pécticos y nucleicos; además preservan la arquitectura de la pared celular y evitan la sobrecoloración (15).

Dentro del proceso diagnóstico microbiológico que incluye coloraciones, se debe incluir el control de calidad, mediante la realización de la tinción de un agente infeccioso ya identificado, el cual será el control positivo. 


\section{Examen microscópico de muestras clínicas sin tinción}

Es el montaje directo húmedo o examen en fresco, en el cual las muestras se extienden directamente sobre la superficie de un portaobjetos para su observación. El material que es demasiado espeso para permitir la diferenciación de sus elementos puede diluirse con igual volumen de solución salina y a continuación se deposita un cubreobjetos sobre la superficie del material.

Fotografía 1. Nemátodo en solución salina. /L. Corrales.

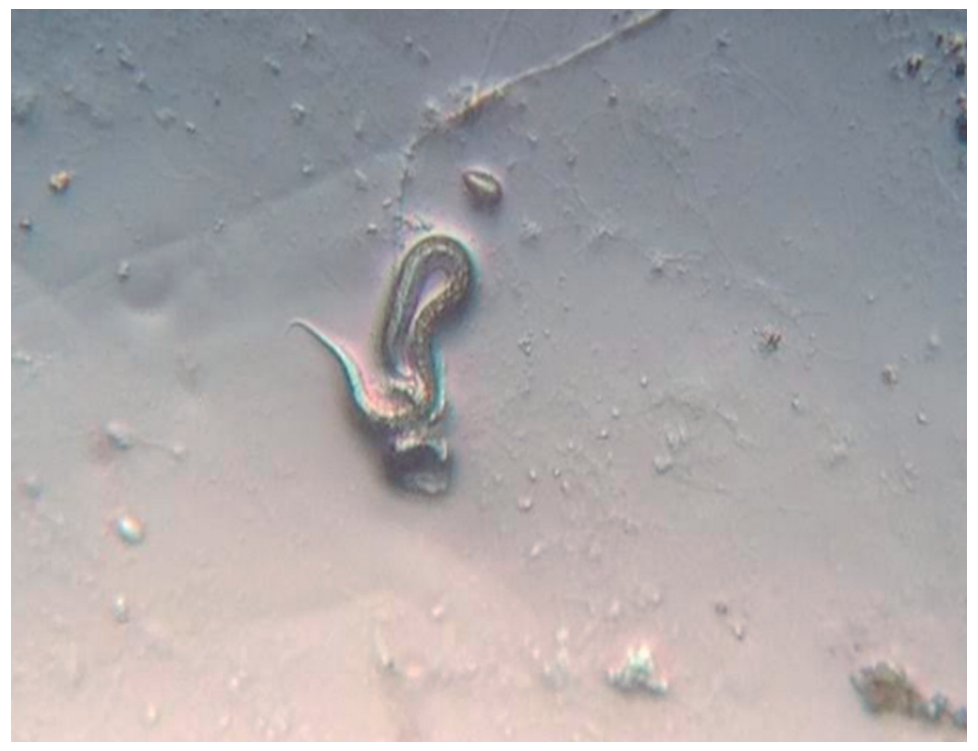

Este tipo de preparación se emplea para detectar trofozoítos móviles de parásitos intestinales como Giardia, Entamoeba, huevos y quistes de otros parásitos, larvas y gusanos adultos, Trichomonas, hifas de hongos o vaginosis causada por Gardnerella vaginalis (16).

\section{Examen microscópico de las muestras clínicas con tinciones}

Como se mencionó anteriormente, los colorantes pueden ser básicos o ácidos, depen- diendo de si la carga es positiva o negativa; entre los primeros se encuentran el azul de metileno, cristal violeta y safranina, mientras que en el segundo grupo se encuentra además de la eosina, la nigrosina.

Por su parte, los colorantes liposolubles se mezclan con los lípidos celulares y los tiñen, este es el caso del Negro Sudán (17).

Los ácidos y las bases libres son, en general, poco solubles, por lo que en microbiología se utilizan casi exclusivamente las sales de los ácidos y de las bases colorantes. Los lla- 
mados colorantes básicos contienen un catión coloreado unido a un anión incoloro y los ácidos constan de un catión incoloro unido a un anión coloreado.

Los básicos son los más usados en bacteriología, debido a que las bacterias, ricas en ácidos nucleicos, portan cargas negativas en forma de grupos fosfato, los que se combinan con los colorantes cargados positivamente. Dentro de éstos los más empleados son: tionina, azul de toluidina, azul de metileno, fucsina, cristal violeta, violeta de genciana, verde metilo, safranina y verde de malaquita; y entre los ácidos se encuentran naranja G, ácido pícrico, fucsina ácida y eosina.

Los colorantes ácidos se utilizan en técnicas especiales, coloraciones negativas o para teñir algunas estructuras bacterianas, fun- damentalmente citoplasmáticas. Existe un grupo de sustancias, cuya base y ácido tienen carácter colorante, y son denominadas colorantes neutros. Entre ellos se encuentran los eosinatos como el de azul de metileno, azul de toluidina y violeta de metilo (18).

\section{Tinción simple}

En estas se utiliza un solo colorante, por lo que todas las estructuras celulares se tiñen con la misma tonalidad (tinta china, azul metileno de Löeffler, azul de lactofenol). Se basa en el hecho de que las células tienen una composición química diferente a la de su entorno, de modo que ambos se comportan de forma diferente frente al colorante $(19,20,21)$.

Fotografía 2. Estructura micótica coloreada con azul de lactofenol. /L. Corrales.

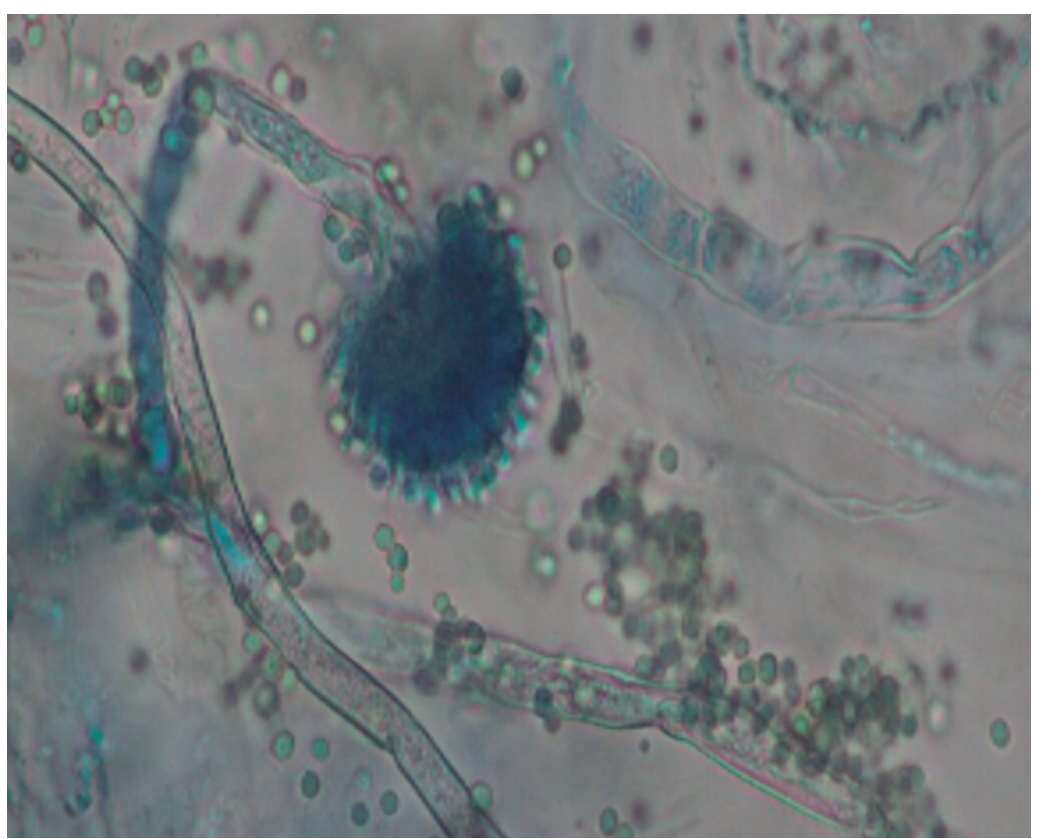




\section{Tinción diferencial o compuesta}

En estas se utilizan varios colorantes combinados, las estructuras celulares se diferencian en función de los colorantes que fijan. Se basan en el hecho de que distintos tipos de células tienen distinta composición química; y por lo tanto, reaccionan de forma diferente frente a una tinción, lo que permite clasificar los microorganismos en diferentes grupos. Los ejemplos clásicos serían la tinción de Gram o la de Ziehl-Neelsen $(19,20)$.

\section{Tinción selectiva}

Se basan en el hecho de que existen estructuras celulares con una composición química determinada afín por uno de los colorantes que se aplican en la tinción, de modo que se tińen selectivamente como las esporas, los flagelos y los gránulos metacromáticos, entre otros $(19,20)$.

\section{Coloraciones más frecuentes en microbiología}

\section{Coloración de Echyo Riv}

Es una técnica de coloración simple que permite observar la morfología bacteriana, sea esta respectivamente de cocos, bacilos, espirilos o espiroquetas. Todas las estructuras se tiñen de la misma tonalidad. Para esta coloración se usa la fucsina y el bicarbonato de sodio ( $\mathrm{NaHCO} 3)$. Es una coloración simple, por lo que las células se teñirán de un mismo color.

La bacteria tiene una carga negativa conferida por el citoplasma y los ácidos nucleicos, mientras que la fucsina tiene una carga básica (catiónica); por lo tanto, por atracción electrostática se atraen; y el bicarbonato ayuda en la estabilización de cargas (20, 22).

Fotografía 3. Espiroquetas coloreadas por la técnica de Echio Riv./ L.Corrales.

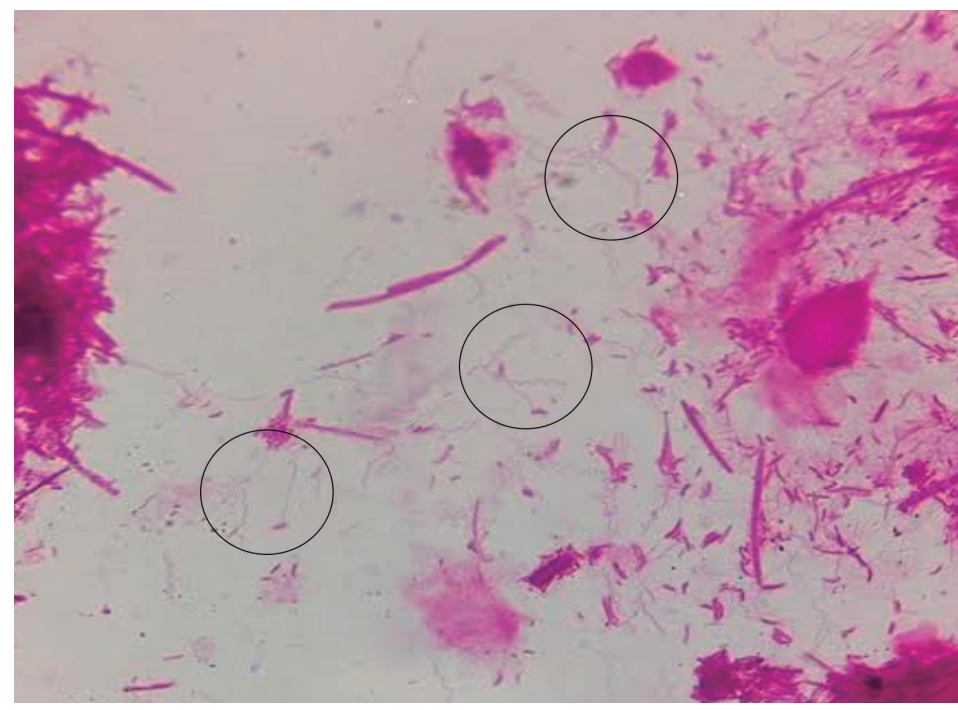




\section{Tinción de Gram}

En bacteriología la tinción de Gram es una herramienta fundamental para diferenciar distintos tipos de bacterias según su coloración, morfología y asociación (23). En 1884, el Doctor Chistian Gram desarrolló esta técnica y de acuerdo a los componentes estructurales que presentan las bacterias se pueden clasificar en Gram positivas y Gram negativas, de acuerdo con la composición de su pared (24). La pared bacteriana, corresponde a la estructura que da forma a la célula y la protege de lisis osmótica, acción de sustancias tóxicas y es el lugar sobre el cual actúan varios antibióticos $(25,26)$.

Figura 6. Estructura de la pared bacteriana de Gram positivas y Gram negativas / L. C. Corrales., A. P. González.

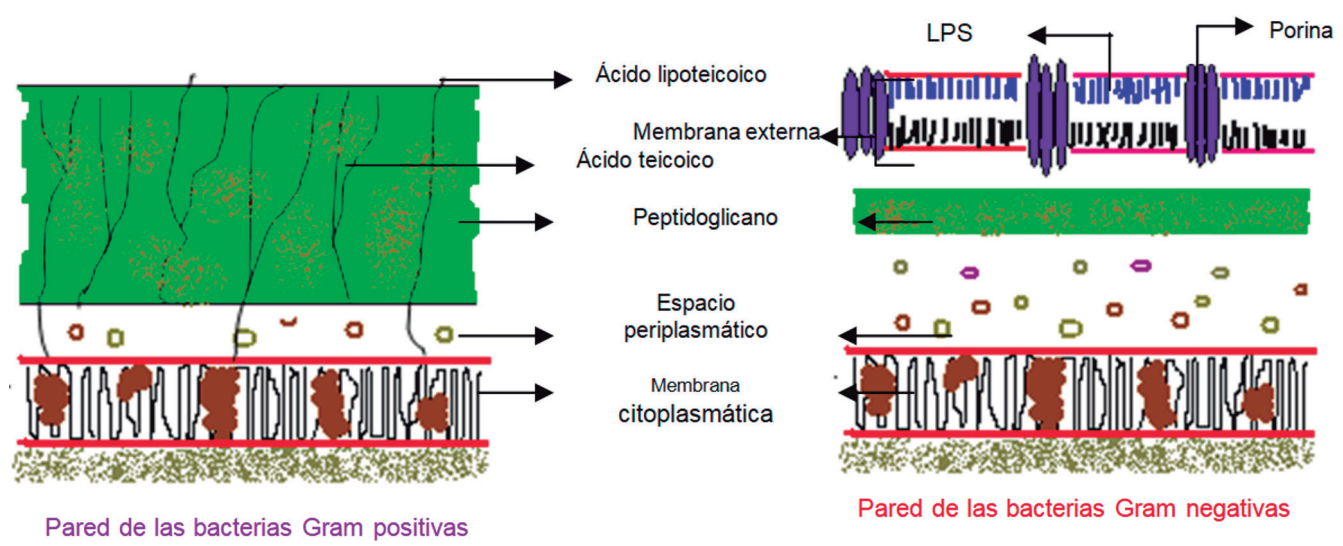

Los principios de la tinción de Gram están basados en las características de la pared celular de las bacterias, la cual le confiere propiedades determinantes a cada microorganismo. La pared celular de las bacterias Gram negativas está constituida por una capa fina de péptidoglicano y una membrana celular externa, mientras que las bacterias Gram positivas poseen una pared celular gruesa constituida por péptidoglicano, pero no cuentan con membrana celular externa. Así pues, la composición química y el contenido de péptidoglicano en la pared celular de las bacterias Gram negativas y
Gram positivas explica y determina las características tintoriales $(16,26)$.

Esta tinción se basa en colocar como colorante primario cristal violeta, el cual tiene afinidad por el péptidoglicano de la pared bacteriana. Posteriormente, se coloca lugol, el cual sirve como mordiente e impide la salida del cristal violeta por la formación de un complejo cristal violeta-yodo que satura los espacios del péptidoglicano de la pared bacteriana. Posteriormente, se aplica una mezcla de alcohol-acetona, la cual deshidrata la pared bacteriana y cierra los 
poros de la misma. También destruye la membrana externa de las bacterias Gram negativas, debido a que esta es soluble a la acción de solventes orgánicos, como la mezcla de alcohol-acetona. Las bacterias Gram positivas, al contener una gran cantidad de péptidoglicano, retienen con mayor fuerza este complejo, mientras que las Gram negativas no lo pueden retener por poseer menos cantidad de péptidoglicano. Por último, se coloca fucsina, la cual actúa como coloran- te secundario o de contratinción y tińe las bacterias que no logran retener el complejo cristal violeta-yodo.

Hay bacterias de un mismo género que pueden observarse en la misma muestra como Gram positivas y como Gram negativas, a esto se le denomina tinción Gram variable, secundaria a alteración en nutrientes, estructuras, temperatura, $\mathrm{pH}$ o concentración de electrolitos en la célula.

Fotografía 4. Tinción de Gram de muestra de secreción vaginal. Se observan células guía en vaginosis bacteriana, con flora bacteriana Gram variable. / L. Corrales.

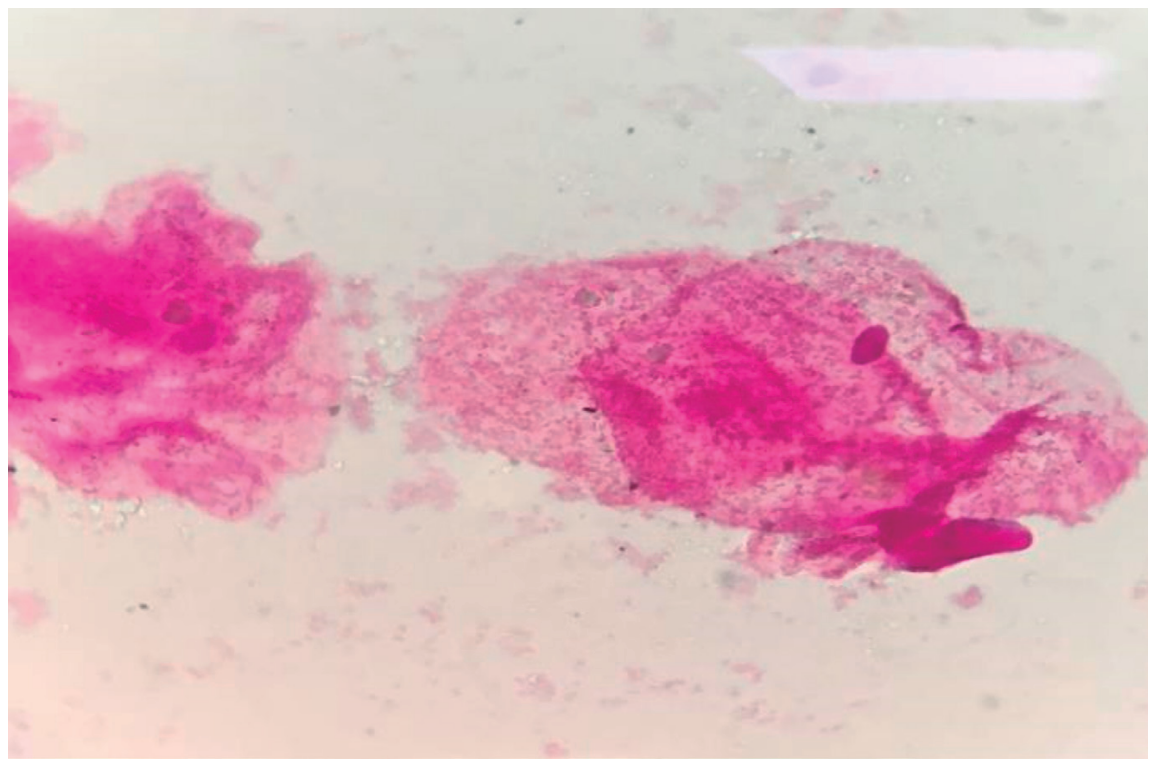

No todas las bacterias se tiñen por esta técnica, pues hay algunas que carecen de pared celular, como mycoplasmas (27) o su pared celular tiene una composición química diferente como las micobacterias, que cuentan con una gran cantidad de ácidos micólicos y requieren otro tipo de coloraciones específicas $(22,28)$.
Figura 7. Estructura molecular de cristal violeta.<smiles></smiles> 
El cristal violeta corresponde al nombre común asignado a un tipo de colorantes en los que se encuentra una mezcla de $\mathrm{N}$-tetra, $\mathrm{N}$-penta y $\mathrm{N}$-hexametil p-rosanilinas. Específicamente, el reactivo usado para la prueba de Gram corresponde al derivado que tiene 6 sustituciones metílicas. Precisamente, debido a la alta sustitución de grupos metilo, éste compuesto es el que brinda una tonalidad violeta más oscura y se conoce como violeta 10B. Los grupos metilo son los que se constituyen en los auxocromos responsables, en buena parte, de la formación del enlace complejo que da origen a la tinción $(8,9)$.

\section{Reactivo de Lugol}

Lo primero que hay que aclarar con respecto al reactivo de Lugol es que no corresponde a una sustancia pura; es decir, no es un compuesto con una formula química específica, sino que su acción se debe precisamente a la mezcla en forma homogénea y en solución acuosa de Yoduro de Potasio (KI) y Yodo (I2).

Así la solución de lugol está compuesta por una mezcla saturada de Yodo, que deja disponible a este elemento para que reaccione en forma de iones.

$\mathrm{KI}+\mathrm{I}_{2} \rightarrow$ mezcla saturada de yodo soluble en agua

El reactivo denominado 'Lugol', fue utilizado por primera vez por el Dr. Jean Guillaume Auguste Lugol (1786-1851) (29), quien utilizó esta solución para tratar la escrófula (conocida comúnmente como la enfermedad de las paperas). El proceso infeccioso es causado por el Mycobacterium tuberculosis. El doctor en mención realizó publicaciones en las que resaltaba el tratamiento para dicha enfermedad utilizando una solución en la que se mezclaban Yodo (I) con Yoduro de Potasio (KI). Posteriormente, y con base en estas investigaciones, se implementó el uso del elemento yodo en el tratamiento de la enfermedad del bocio (30).

\section{Alcohol-Acetona}

Estos dos compuestos actúan en forma de solución y dan origen a un reactivo que, al igual que el lugol, no corresponde a una sustancia pura. La solución alcohol-acetona, tiene propiedades deshidratantes que permiten en primera instancia la captura de las moléculas de agua de la membrana, debido a interacciones moleculares que se explican por la formación de dipolos entre las moléculas. De esta manera, se entiende el efecto decolorante en las paredes de las bacterias gramnegativas, teniendo en cuenta que el alcohol-acetona desorganiza dichas membranas constituidas principalmente por lipoproteínas y lipopolisacáridos lo que permite la salida del colorante primario (cristal violeta).

Figura 8. Mezcla de propanona y etanol.<smiles>CC(=O)[CH+]CCO</smiles> 
Figura 9. Estructura Molecular de la Fuscina Básica.<smiles></smiles>

La fuscina básica, como colorante de contraste, corresponde al reactivo denominado Violeta Ácido 19, que a su vez es identificado por la fórmula química condensada de: $\mathrm{C}_{20} \mathrm{~N}_{3} \mathrm{H}_{17} \mathrm{O}_{9} \mathrm{~S}_{3} \mathrm{Na}_{2}$. La función específica de contraste se explica por la presencia tanto de los anillos como del grupo $\mathrm{NH}_{2}$ y su función es hacer visibles a las bacterias Gram negativas debido a la formación de un complejo coloreado "rojo" (31).

La pared celular de las bacterias Gram positivas logra la retención del primer colorante, debido al espesor aproximado de $80 \mathrm{~nm}$ del entramado de varias capas de péptidoglicano, por lo cual, no toma la fuscina.

Fotografía 5. Tinción de Gram de una muestra directa de secreción uretral, se observan los Polimorfonucleares Neutrófilos y diplococos Gram negativos intracelulares. /L. Corrales.

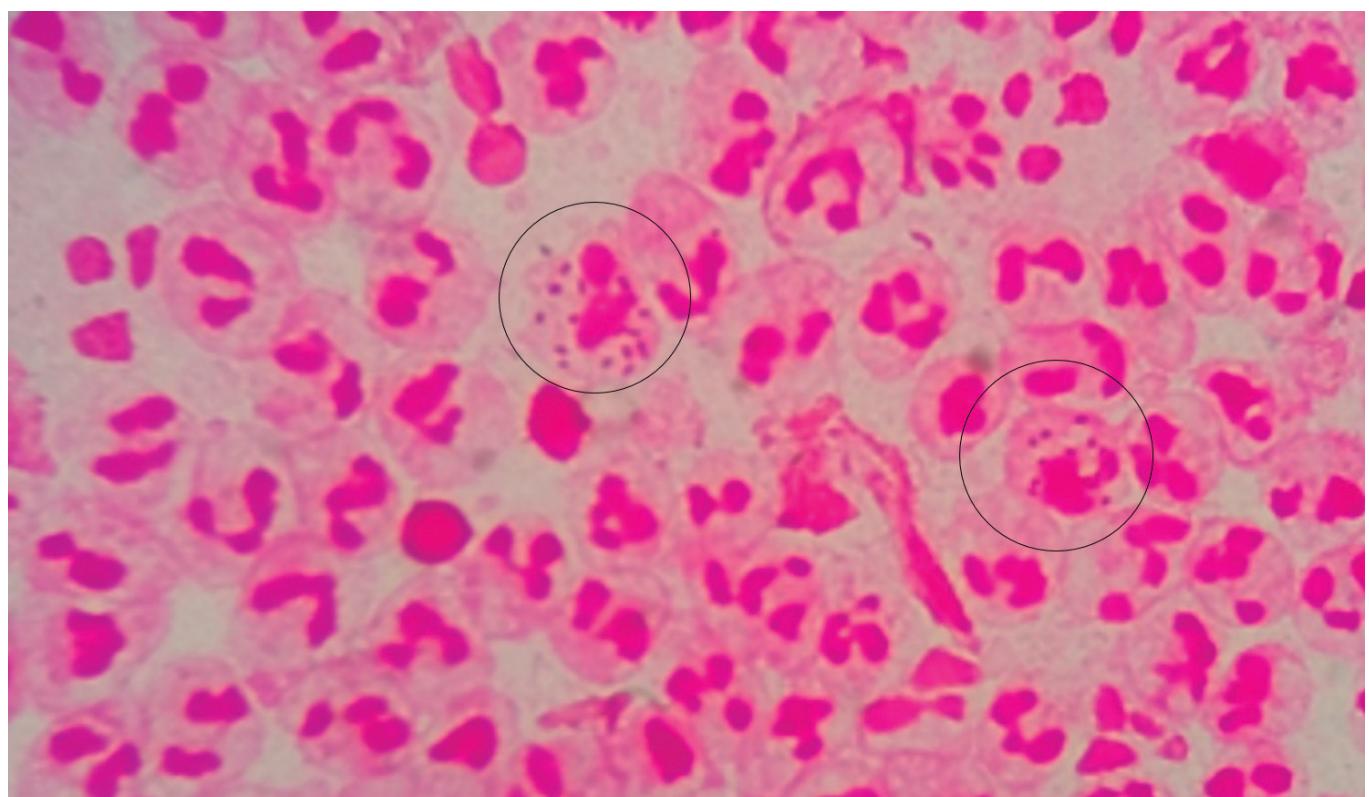


El reporte se realiza de acuerdo a la morfología, asociación y color observado.

Fotografía 6. Flora mixta al Gram / L. Corrales.

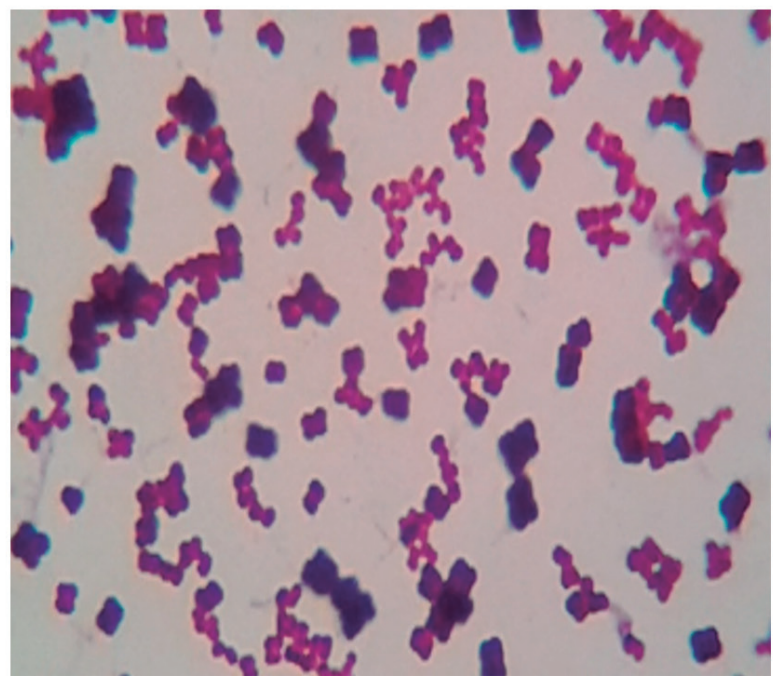

Fotografía 7. Diplococos Gram negativos/L. Corrales.

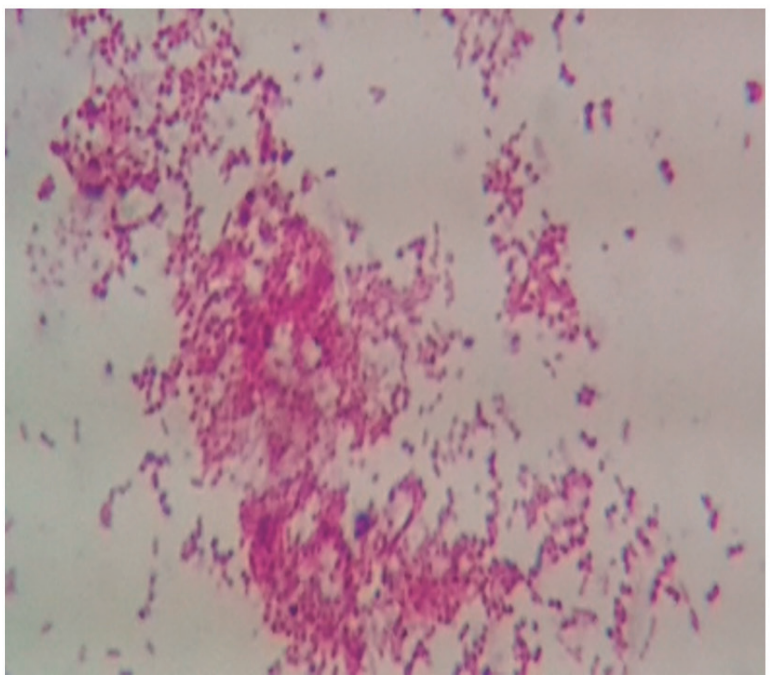

Fotografía 8. Bacilos Gram positivos/L. Corrales.

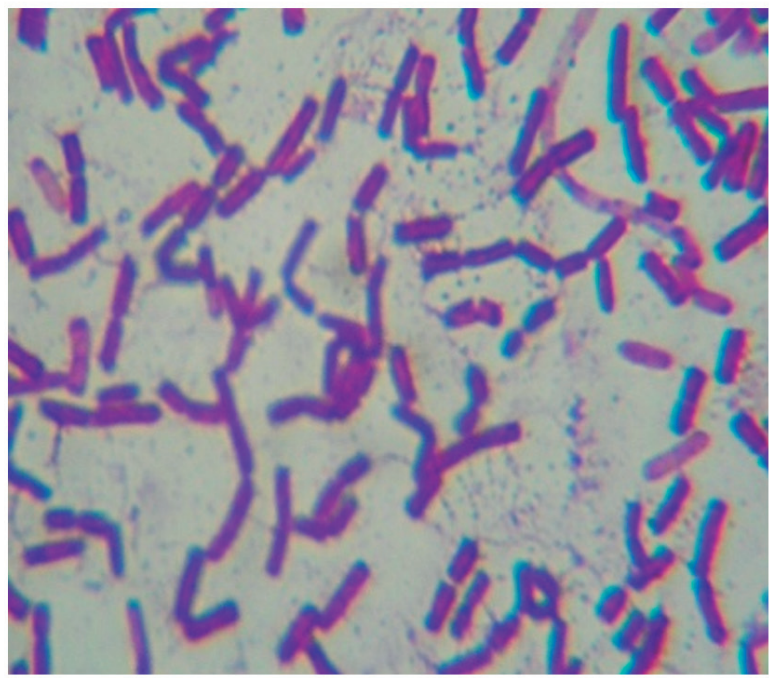

Para el reporte del informe, es importante, tener en cuenta:

Forma: cocos (esféricos), bacilos (bastones, cilindros), cocobacilos (bastones cortos, ovoidales), vibrios (bacilo en forma de coma), espirilos (bacilos en forma de tirabuzón).

Agrupamiento: aislado (individual), diplos, parejas, tetradas, cadenas, racimos, empalizadas. 


\section{Tinción negativa o Burry}

Este tipo de tinción fue diseñada para microscopía de luz con el fin de rodear y delinear las bacterias no teñidas. Este método es muy útil, de bajo costo y valioso por la información que provee sobre las bacterias que pueden presentar cápsula, ya que proporciona un resultado presuntivo (32). La cápsula está compuesta por una capa adicional de polisacáridos, los cuales se encuen- tran fuertemente unidos a la pared celular y ofrecen permeabilidad a la misma $(33,34)$.

El fundamento es simple: se tiñe el exterior, pero no el interior de células; es decir, no se colorean sus estructuras. Adicionalmente, sólo requiere tinta china como colorante: las partículas de carbono de la tinta no logran penetrar la cápsula, la cual se ve clara sobre el fondo oscuro que provee la tinta china.

Fotografía 9. Bacterias capsuladas con tinción de tinta china / L. Corrales.

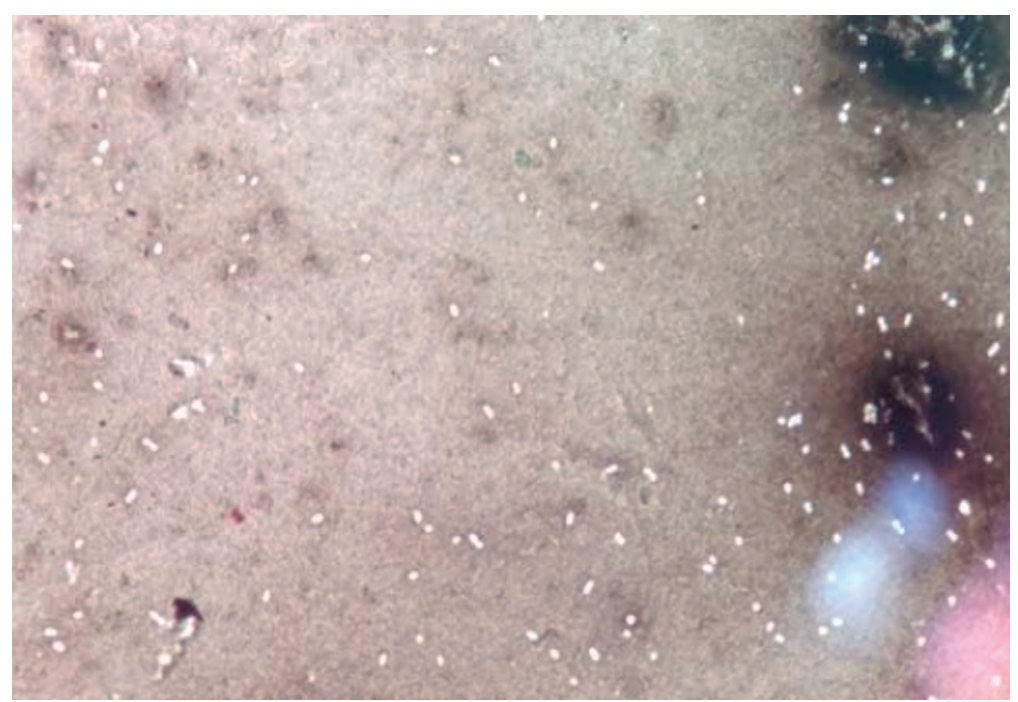

La tinta china da lugar a una suspensión coloidal de carbón, denominada "nigrosina", que corresponde a un colorante ácido. Dichas partículas de carbono no irrumpen en el interior de las bacterias, pero sí colorean el entorno debido a una atracción intermolecular del tipo fuerzas de London (35).

El tamaño de las partículas del colorante, por tener características coloidales, incide en el proceso de tinción del medio ya que dicho proceso no sería posible con una solución líquido-sólido convencional, por efectos de la miscibilidad (36).

\section{Coloración de azul de metileno de Löeffler}

El azul de metileno se reconoce como un colorante sencillo que puede ser utilizado para fines diversos, tales como la determinación de la morfología bacteriana. 
Figura 10. Estructura Molecular del azul de metileno.<smiles>CN(C)c1ccc2nc3ccc(=[N+](C)C)cc-3sc2c1</smiles>

El nitrógeno cargado positivamente (catión) se constituye en el centro activo de la molécula; y por tanto, desde allí se explican las tinciones electrofílicas a partir de este compuesto, y la atracción hacia aniones tales como los grupos fosfato $\left(\mathrm{PO}_{4}\right)^{-3}(31)$.

En este sentido, es el colorante preferido para la identificación presuntiva de Corynebacterium diphtheriae, aunque también se utiliza para la identificación de espirilos y bacilos lácticos. Este microorganismo presenta dilataciones regulares características de uno de sus polos, lo cual le da una apariencia de maso. Dichas inclusiones corresponden a gránulos que contienen ácido polifosfórico, el cual es un polímero inorgánico del ácido fosfórico $\left(\mathrm{HO}\left(\mathrm{PO}_{2} \mathrm{OH}\right)\right.$ $\mathrm{nH})$. La asociación en dichos gránulos da lugar a un efecto metacromático que a su vez produce una tinción más intensa con los colorantes de anilina, como es el caso del azul de metileno alcalino de Löeffler. Para el resto del bacilo, la tinción es menos marcada con un azul más claro, obteniendo como resultado de la tinción, una apariencia de rosario al teñirse.

La parte interna de los cúmulos está constituida por un núcleo formado por moléculas apolares de lípidos y proteínas; mientras que, en la periferia, como se anotó anteriormente, se encuentran los polímeros de polifosfato, dando lugar a un mecanismo osmóticamente inerte de almacenamiento de grupos fosfato.

El azul de metileno también se utiliza como un complemento de la tinción de Gram, especialmente para la tinción de bacterias Gram-negativas, tales como Haemophilus influenzae y especies de Neisseria. El colorante puede revelar la morfología de las bacterias fusiformes y espiroquetas (de infecciones orales, tales como la angina de Vincent) que apenas puede distinguirse con la tinción de Gram (36). El colorante también se utiliza para detectar la presencia de leucocitos en heces, que puede delatar la presencia de una enteropatía invasiva.

Fotografía 10. Bacilos con gránulos metacromáticos teñidos con azul de metileno de Löeffler/L. Corrales.

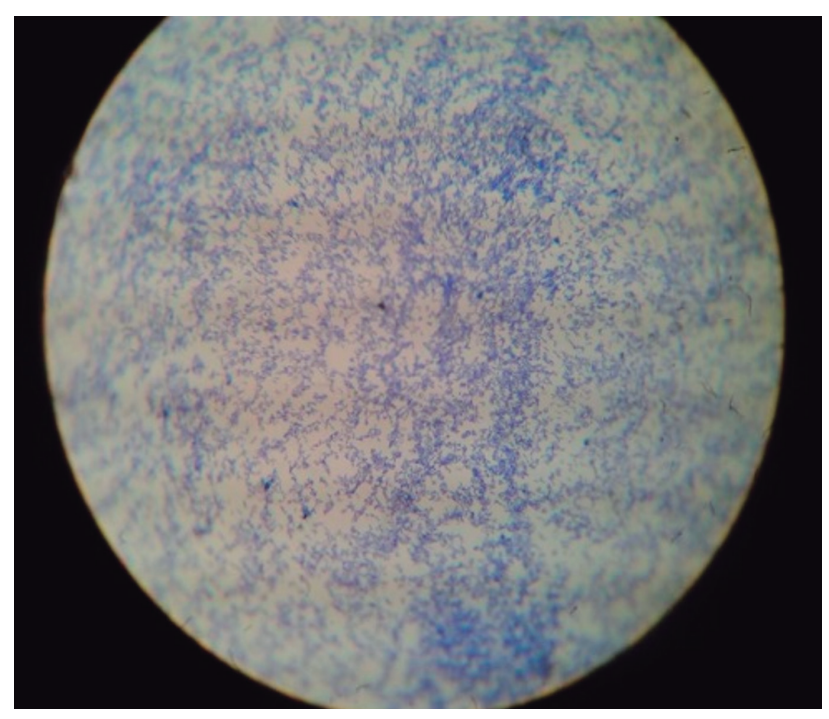




\section{Coloración de Van Stoltemberg}

También es una coloración específica para gránulos metacromáticos y tal como se estableció anteriormente, estos gránulos están formados por polifosfato y polímeros lineales del ortofosfato, los cuales representan una asociación molecular osmóticamente inerte de almacenamiento de fosfato, debido a que la parte central de los gránulos está constituida por un núcleo de macromoléculas de lípidos y proteínas (37).

Las inclusiones son cuerpos inertes en las células. Muchas de ellas son materiales alimenticios de reserva, dado que se acumulan durante tiempo de aporte nutricional y disminuye la duración de la inanición. El carácter de las inclusiones varía con el organismo. En muchas especies bacterianas y en hongos, algas y protozoarios aparecen gránulos de volutina, llamados gránulos metacromáticos. Se les colorea intensamente con colorantes básicos debido a la alta concentración de ácido fosfórico polimerizado, conocido como polifosfato. El colorante Van Stoltemberg está compuesto por fucsina y verde de malaquita (colorantes catiónicos básicos). Su fundamento radica en que la fucsina es tomada por el polifosfato y de esta forma se observan los gránulos de color rojizo y el verde de malaquita es tomado por el cuerpo del bacilo, viéndose de color verde $(22,38)$.

Fotografía 11. Bacterias con gránulos metacromáticos teñidas con Van Stoltemberg/ L.

Corrales.

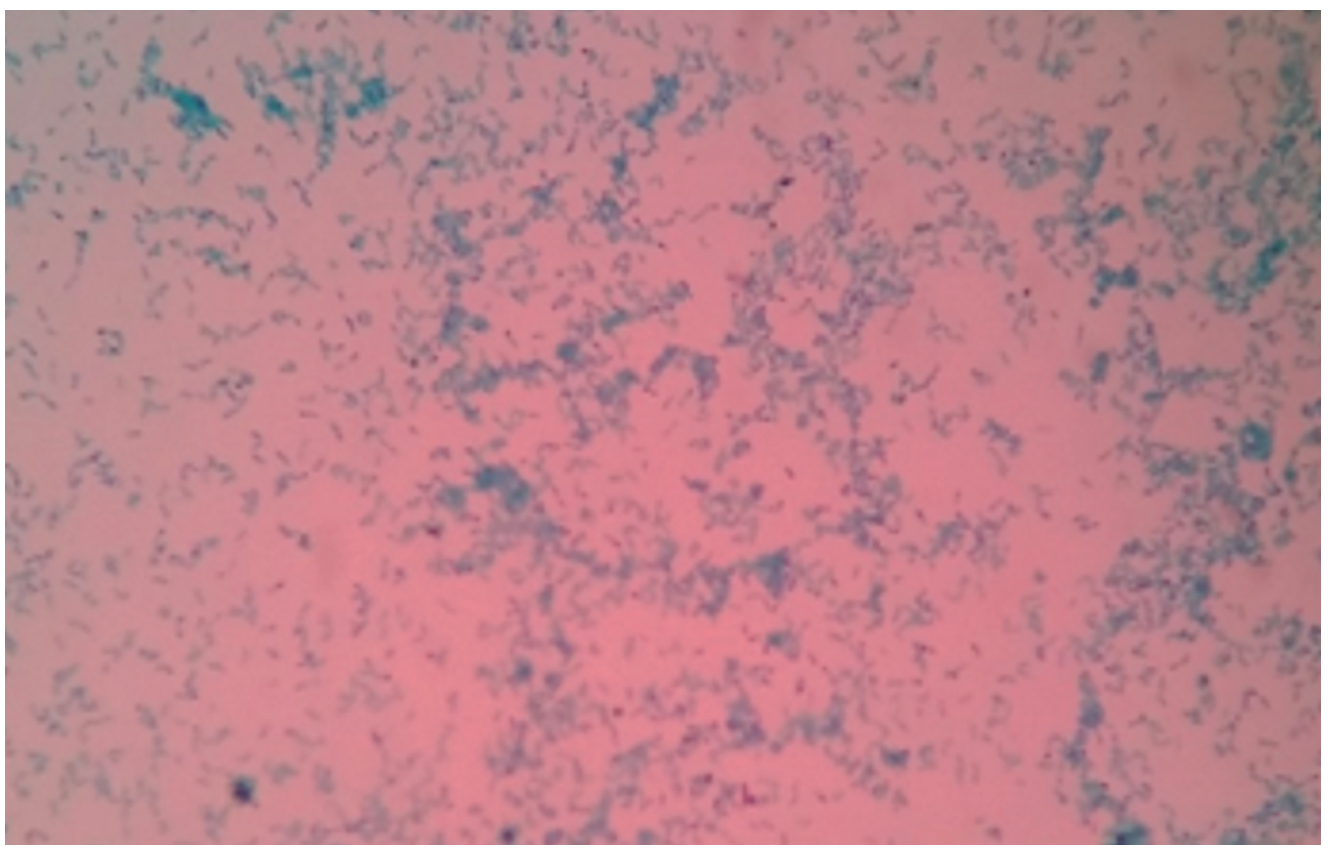




\section{Coloración de Shaeffer Foulton}

Las esporas son estructuras bacterianas constituidas por proteínas, calcio y ácido dipicolinico $\left(\mathrm{C}_{10} \mathrm{H}_{2} \mathrm{O}_{4} \mathrm{~N}\right)$.

Figura 11. Estructura Molecular Acido Dipicolínico.<smiles>O=C(O)c1cccc(C(=O)O)n1</smiles>

Este compuesto engloba el ADN y causa resistencia a factores ambientales o condiciones adversas, tales como altas temperaturas, baja humedad, radiaciones y agentes químicos. Según su localización, se distinguen tres tipos de esporas: centrales, subterminales y terminales, que presentan en particular los géneros Bacillus y Clostridium.

El proceso de esporulación conlleva una serie de eventos codificados desde el genoma bacteriano e incluye los siguientes pasos: 1 . El cese en la provisión de los nutrientes, lo cual implica que el crecimiento bacteriano se detenga. 2. La formación de un filamento axial de material genético. 3. El plegamiento de la membrana celular para englobar el ADN y producir el septo. 4. El crecimiento de la membrana continua, formando la membrana externa o exina. Ubicada por fuera del córtex también se encuentra una segunda membrana denominada interna o intina. 5. Producción del córtex en la espora, situado entre las dos membranas (exina e intina), donde se acumula el calcio y el ácido dipicolínico, 6. Formación de la cubierta de proteínas. 7. Formación del exosporio que corresponde a la última capa. Y 8. Liberación de la espora (34). Entre las transformaciones químicas y físicas que acompañan a los cambios morfológicos se encuentran: 1. Concentración del material proteico en la zona de formación de la espora. 2. En razón de la concentración del material, aumenta el índice de refracción de la zona. 3. Utilización del material de reserva (ácido poli-beta-hidroxibutírico, en anaerobios y polisacáridos en aerobios) para procesos de degradación y síntesis. 4. Síntesis de ácido dipicolínico, específico de las esporas y que no se encuentra en las células vegetativas. Este ácido se combina en forma de quelato con iones $\mathrm{Ca}++$; se localiza en el protoplasto de las esporas termorresistentes y 5. Liberación por autolisis de las células maternas (39).

Las esporas son altamente impermeables a los colorantes, de manera que con las técnicas de coloración comunes como la de Gram, se observan como regiones sin teñir dentro de las células coloreadas y por esto se deben utilizar métodos especiales y selectivos de coloración. Una vez coloreada, la espora resiste fuertemente la decoloración y el contraste.

La tinción selectiva de Shaeffer Foulton (40) para esporas se fundamenta en que el verde de malaquita es un colorante débilmente básico (tiene una carga positiva débil) y, por tanto, se une débilmente a la bacteria de tal forma que penetra en las células vegetati- 
vas y cuando se calienta la preparación por cierto tiempo también penetra las esporas, ya que el calor modifica la permeabilidad de estas y permite la entrada del colorante a través de sus capas externas. Es utilizado como colorante primario y durante el lavado con agua, el verde malaquita se elimina de las células vegetativas, pero no de la espora. Aquí es donde entra el colorante de contraste fucsina de Shaeffer Foulton, que solo puede teñir a las células vegetativas decoloradas por acción del agua (41).

Figura 12. Estructura molecular verde de malaquita.<smiles>CN(C)c1ccc(C(=C2C=CC(=[N+](C)[O-])C=C2)c2ccccc2)cc1</smiles>

El verde de malaquita en su forma incolora ingresa al citoplasma de la célula debido a su polaridad y por atracciones de tipo catiónico propiciadas por el calor, reacciona y colorea el interior de las células vegetativas y las esporas. Al lavarlo con agua se aumenta la polaridad $(42,43)$ y el colorante se disuelve y sale del interior de la célula, pero no de la espora debido a la presencia de los cúmulos de quelatos que se forman entre el ácido dipicolinico y el calcio. La acción de la fuscina se verifica con la coloración exclusiva de las células vegetativas.

Fotografía 12. Células bacterianas con espora teñidas con Shaeffer Foulton / L. C. Corrales.

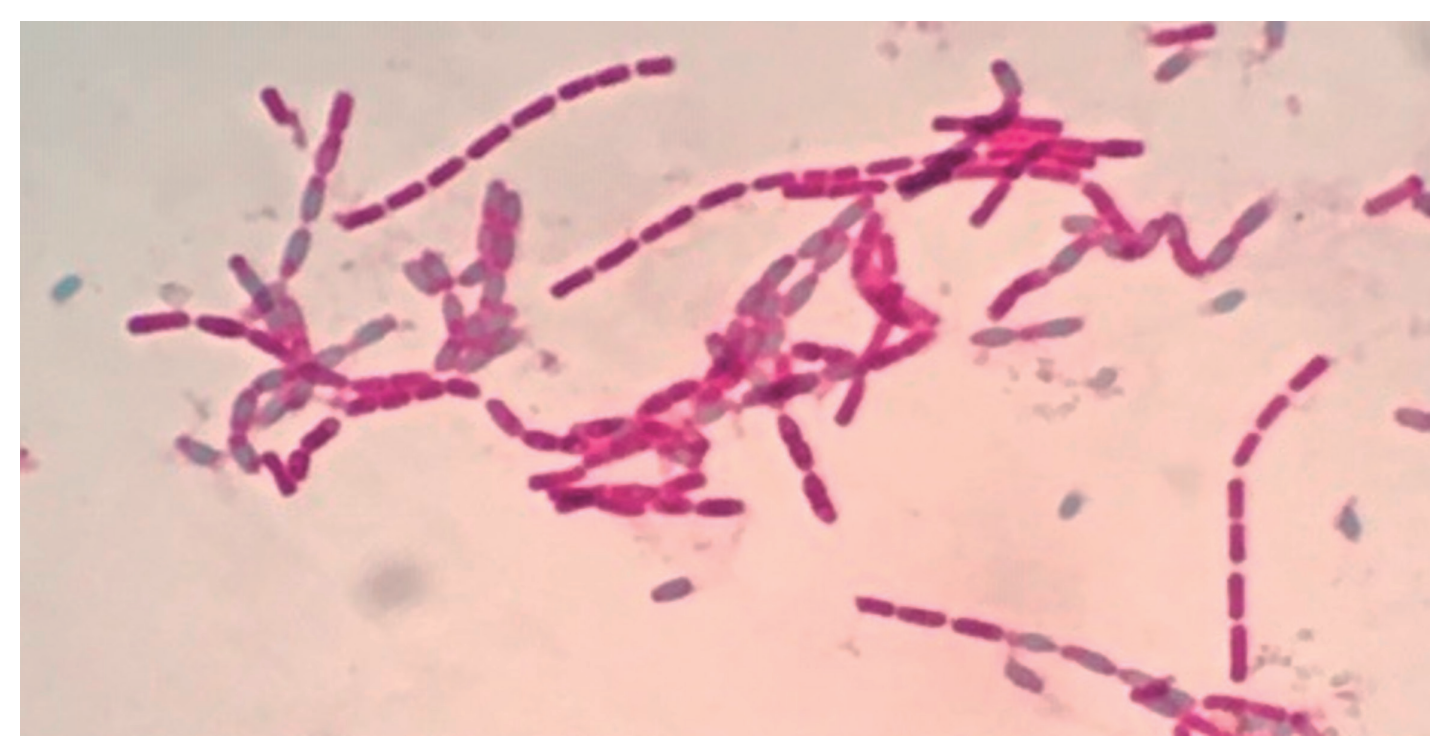


En la Fotografía 12, se observan bacterias de forma bacilar con presencia de esporas, la célula vegetativa se tiñe de rojo y la espora de verde.

\section{Coloración de Ziehl Neelsen (BAAR)}

Es una tinción diferencial utilizada para la identificación de bacterias que cuentan con la propiedad fisicoquímica de ser ácidos alcoholes resistentes (BAAR); y por lo tanto, no son reactivas con la fuscina básica. Un ejemplo lo constituye el género Mycobacterium.

La pared de estas bacterias está constituida por péptidoglicano unido mediante enlaces covalentes a un polímero de ácidos micólicos que a su vez se asocian a unidades de azúcar como galactosa-arabinosa. A este tipo de macromoléculas se les ha asignado el nombre general de "arabinogalactano", el cual debido al tamaño y al efecto estérico le confiere carácter hidrofóbico a la bacteria.

Químicamente, los arabinogalactanos corresponden a glucoproteínas en las que la proporción del carbohidrato es muy superior con respecto a la parte proteíca, lo cual le otorga a este tipo de moléculas gran solubilidad en agua $(8,44,45)$.

A su vez, los ácidos micólicos están constituídos por arabinosas distales, que forman ésteres de ácidos grasos alfa ramificados y beta hidroxilados de 60 a 90 átomos de carbono. Estos ácidos forman una envol- tura hidrófoba que se une en la parte más externa a lípidos complejos, los cuales son específicos de las micobacterias como micerosatos de tiocerol, glucolípidos fenólicos, lipooligosacáridos, sulfolípidos y demicolato de trehalosa $(20,46)$. Adicionalmente, algunas micobacterias poseen sobre los lípidos superficiales, glucanos, proteínas como porinas y lipoarabinomananos, las cuales le confieren mayor capacidad hidrofóbica, debido a la presencia del efecto estérico y al alto peso molecular. Precisamente, esta resistencia polar es la que explica la ácido alcohol resistencia, ya que resisten la decoloración con ácidos fuertes después de ser coloreadas con solución de fucsina fenicada sometida a calentamiento.

La coloración clásica de Ziehl-Neelsen se basa en el calentamiento inicial que permite aumentar tanto la energía cinética de las moléculas del colorante (fuscina de Ziehl Nielsen), como alcanzar rompimiento de las estructuras cristalinas de las ceras, favoreciendo así el ingreso del colorante a la pared bacteriana y al interior de la célula. $\mathrm{Al}$ suspender el calentamiento y enfriar con agua, se provoca una nueva solidificación de los ácidos grasos (ceras) de modo que el colorante queda atrapado dentro de dichas estructuras cristalinas y ya no puede salir de las bacterias $(39,45)$.

Al normalizarse la temperatura de la preparación, el compuesto lipídico impermeabiliza la pared a la acción del decolorante ácido, con lo cual el microorganismo se mantiene teńido. Las bacterias que resisten 
la decoloración son de color rojo y las que no, se ven de color azul con el colorante de contraste azul de metileno de Ziehl Neelsen. Así mismo, las células epiteliales y otras células, que no disponen de ácido micólico en su pared o membrana, son decoloradas, después de teñidas por la fucsina, quedando incoloras y posteriormente tińéndose de azul (47).

Figura 13. Pared de las micobacterias/ L.Corrales.

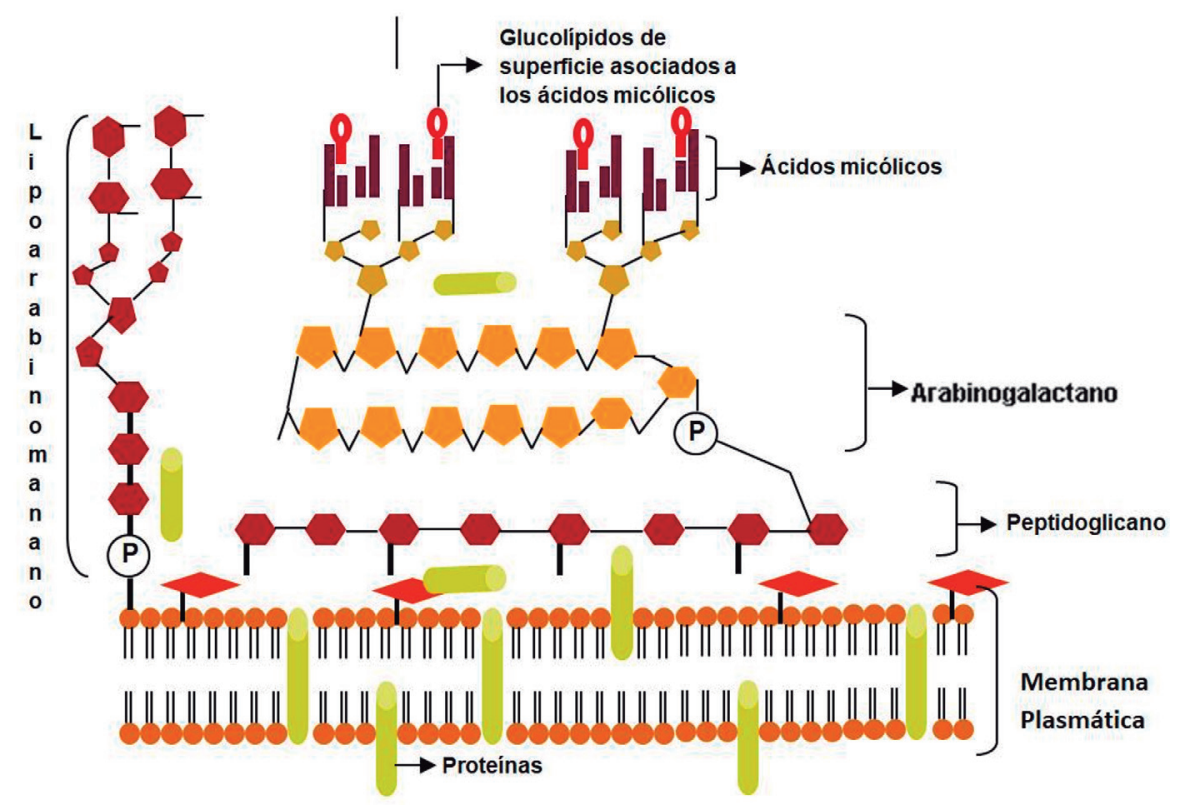

Fotografía 13. Células bacterianas coloreadas con Ziehl Neelsen /L.Corrales.

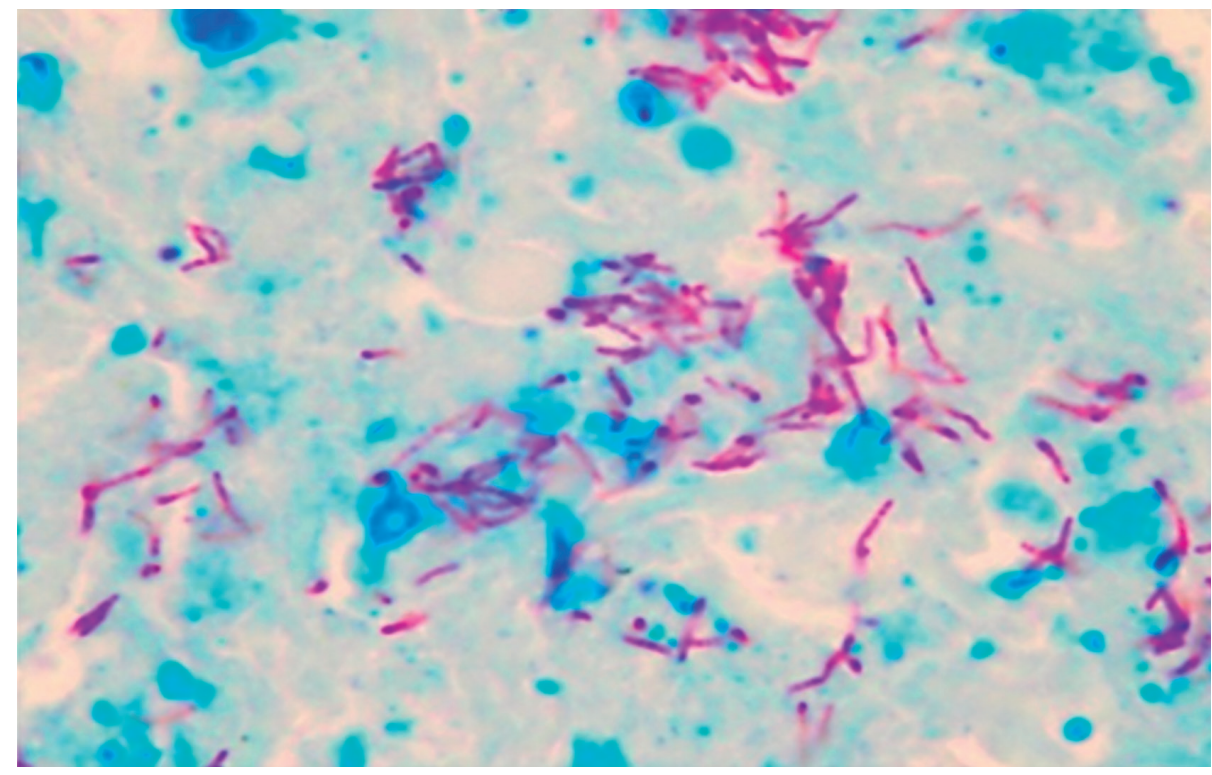


la decoloración son de color rojo y las que no, se ven de color azul con el colorante de contraste azul de metileno de Ziehl Neel- sen. Así mismo, las células epiteliales y otras células, que no disponen de ácido micólico

Figura 14. Representación de la coloración de Ziehl Neelsen en bacterias ácido alcohol resistentes (BAAR) y bacterias ácido alcohol sensibles (BAAS)/ L. Corrales.

\begin{tabular}{|l|l|l|}
\hline Colorantes & Bacterias AAR & Bacterias AAS \\
\hline $\begin{array}{l}\text { Colorante primario } \\
\text { Fucsina fenicada }\end{array}$ \\
\hline $\begin{array}{l}\text { Decoloración con } \\
\text { alcohol ácido }\end{array}$ \\
\hline $\begin{array}{l}\text { Coloración azul de de } \\
\text { Contraste azuleno de Zielh } \\
\text { metileno } \\
\text { Neelsen }\end{array}$
\end{tabular}

\section{Tinción con fluorocromos}

La fluorescencia y la fosforescencia corresponden a fenómenos relacionados con la excitación de los átomos de ciertos materiales, la cual se evidencia en muchos casos con la emisión de luz. La diferencia entre los dos radica en que, en el primero, la emisión cesa en el momento en que se suspenda el estímulo, mientras que en el segundo, la emisión puede continuar por largo tiempo inclusive horas después y en la oscuridad (48).

Algunos colorantes denominados "fluorocromos" poseen propiedades fluorescentes, las cuales se hacen evidentes especialmente en el rango espectral correspondiente a la luz ultavioleta.

\section{Rodamina-auramina}

Los ácidos micólicos de las paredes celulares de las micobacterias poseen afinidad por los fluorocromos auramina y rodamina. Estos colorantes se fijan a las bacterias, que aparecen de color amarillo o naranja brillante contra un fondo verdoso. El permanganato de potasio $\left(\mathrm{KMnO}_{4}\right)$, empleado como contraste, evita la fluorescencia inespecífica. Todos los microorganismos ácido-alcohol resistentes, incluyendo los esporozoarios parásitos, se tińen con estos colorantes.

Un aspecto importante de la coloración rodamina-auramina es que luego los frotis pueden ser reteñidos con la coloración de Ziehl-Neelsen o Kinyoun directamente sobre la tinción con el fluorocromo, si se eli- 
mina antes el aceite de inmersión. De esta forma, los resultados positivos pueden ser confirmados con las coloraciones tradicio- nales, que además permiten la diferenciación morfológica (48).

Fotografía 14. Células bacterianas coloreadas con Auramina Rodamina.

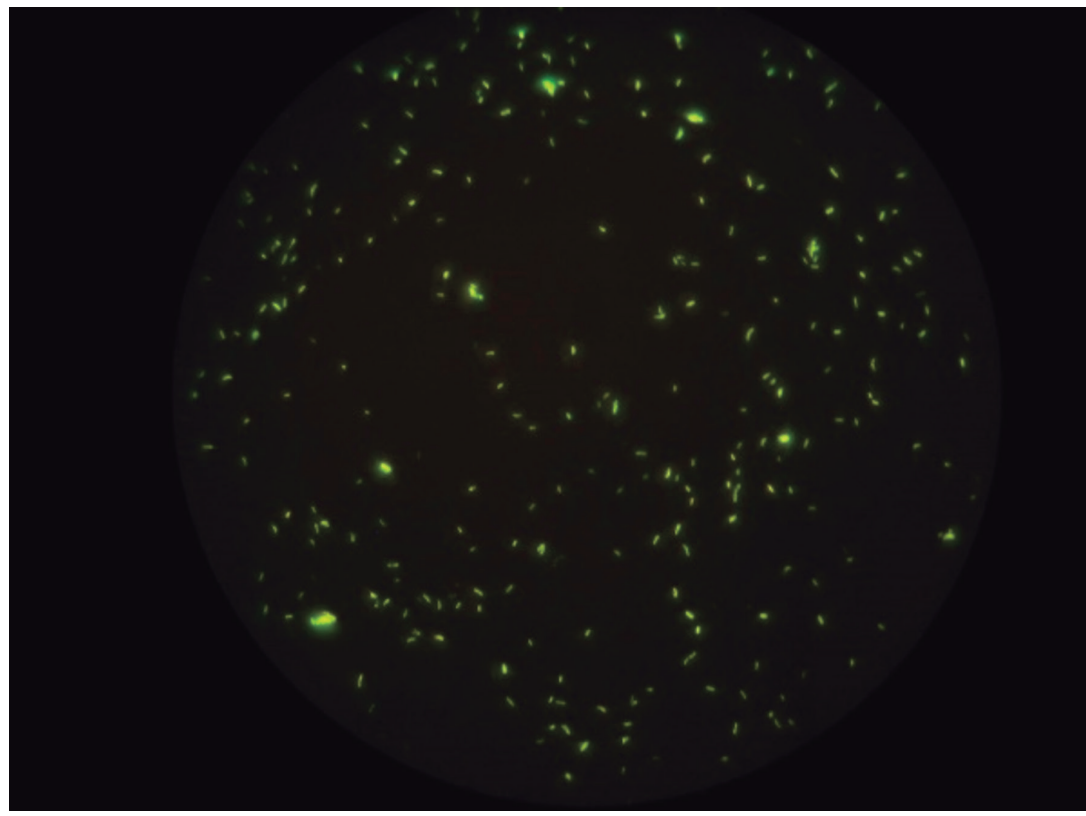

Tomado de:

https://n9.cl/v1lu

En el estudio realizado por Zinserling y cols. (49) se demuestra la mayor sensibilidad de las coloraciones con fluorocromos frente a la de Ziehl Neelsen, concluyendo que "...existe evidencia de la capacidad de las micobacterias para tener polimorfismo morfológico y de la necesidad de aclarar la patogénesis de la tuberculosis".

Además del sistema óptico para la identificación morfológica de los microorganismos, también se cuenta con métodos que hacen uso de microscopios electrónicos, los cuales, disponen de un flujo de electrones que choca contra la muestra, creando una imagen aumentada. En este sistema, se utilizan lentes magnéticas para crear campos que dirigen y enfocan el haz de electrones y ocasionan un espacio vacío que impide que las cargas negativas sean desviadas por las moléculas del aire. Lo anterior puede causar absorciones y emisiones electrónicas en regiones diferentes al espectro visible, lo que implica que las técnicas de coloración para las muestras no sean necesarias (50-51); mientras que, para las observaciones en el microscopio óptico son requeridas, dado que las transiciones electrónicas ocurren a longitudes de onda dentro del espectro visible que se evidencia con los colores. 


\section{Referencias}

1. Decré D, Barbut F, Petit JC. Role of the microbiology laboratory in the diagnosis of nosocomial diarrhea. Pathol Biol (París). 2000; 48: 733-744.

2. Retamales Castelletto E y Manzo Garay V. Recomendaciones para la tinción de frotis sanguíneos para la lectura del hemograma. Instituto de Salud Pública departamento Laboratorio Biomédico Nacional y de Referencia. Instituto de Salud Pública de Chile., (Chile). 2015. Dispónible en: http://www.ispch. $\mathrm{cl} /$ sites/default/files/RECOMENDACIONES\%20 PARA\%20LA\%20TINCI\%C3\%93N\%20DEL\%20 FROTIS\%20SANGU\%C3\%8DNEO.pdf. Consultado 20 de febrero de 2019.

3. Madison BM. Application of stains in clinical microbiology. Biotech Histochem. 2001; 76: 119-125.

4. Capilla Pérea P. Fundamentos de colorimetría. En: Tecnología del color. Universitat de València, Servei de Publicacions. 2002. 15-25.

5. D. Alonso Cerrón-Infantes* y Miriam M. Unterlass* Ecofriendly synthesis of colorants. Revista de Química PUCP, 2018, vol. 32, no 1

6. Flores B, E., Roque P, C., Ochoa L, R. Química del color, Revista de Química. Vol. IX. N² 2. diciembre de 1995 p 99-109.

7. 7. Rivera Rojas L., Fundamentos de Química aplicados a las ciencias de la salud. Bogotá: Ediciones Unisalle., 2018.

8. Fesenden, R. Fesenden, J. Química Orgánica. 2da Edición. Grupo editorial Iberoamérica; 1983.

9. McMurry, J. Química Orgánica. 7a edición. Cengage Learning Editores, S.A. México. 2008.

10. Magdalena M. La Química y los Colorantes en "El carbono y sus compuestos” publicación del Instituto Tecnológico de Estudios Superiores de Monterrey. 2009. Disponible en: http://www.academia.edu/1844623/ La_Qu\%C3\%ADmica_Org\%C3\%A1nica_y_los_Colorantes. Consultado 20 de febrero de 2019.
11. Penney DP, Powers JM, Frank M, Churukian C (2002) analysis and testing of Biological Stains - the Biological Stain Commission Procedures. Biotechnic \& Histochemistry 77: 237-275

12. Vázquez, C. Martín, A. de Silóniz, MI. Serrano, S. Técnicas básicas de Microbiología Observación de bacterias. Reduca (Biología). Serie Microbiología. 3 (5): 15-38, 2010.

13. Piña Mondragón, S. Decoloración biológica del colorante azul directo 2 en un filtro anaerobio/aerobio. T E S I S de grado, PROGRAMA DE MAESTRÍA Y DOCTORADO EN INGENIERÍA, UNIVERSIDAD NACIONAL AUTÓNOMA DE MÉXICO. P. 9 -12. 2007. Disponible en http://www. ptolomeo.unam.mx:8080/xmlui/bitstream/handle/132.248.52.100/1732/pi\%C3\%B1amondragon. pdf?sequence=1. Consultado 20 de Febrero de 2019.

14. Christie, R., Colour chemistry Royal society of chemistry. United Kindgom. (2001), 46, 118-120

15. Calvo GA, Esteban RFJ, Montuenga FL. Técnicas en histología y biología celular. 2nd ed. Madrid Spain: Elsevier; 2009.

16. Forbes, B. Sahm, D. Weissfeld, A. Diagnóstico Microbiológico. Editorial panamericana. 2009.

17. Reynoso, M. Magnoli, C., Barros, G. Mirta, S. Manual de Microbiología General Demo. Unirio Editora. 2015. Disponible en: https://www. unrc.edu.ar/unrc/comunicacion/editorial/repositorio/978-987-688-124-1.pdf. Consultado: 26 de Febrero de 2019 .

18. Tortora, J. Funke, B. Case, C. Introducción a la Microbiología. 9a edición. Editorial Médica Panamericana. 2007.

19. Gamazo, C. Lopez, I. Diaz R. Manual práctico de Microbiología. 3a edición. Editorial Masson. 2005

20. Corrales, L. Ávila de Navia, S. Estupiñan, S. Bacteriología teoría y práctica. Editorial. Universidad Colegio Mayor de Cundinamarca. Bogotá. 2013.

21. Guarner J, Brandt ME. Histopathologic diagnosis of fungal infections in the 21 st century. Clin Microbiol 
Rev. 2011; 24: 247-280 ( montajes en fresco - hongos)

22. Koneman, E. Diagnóstico Microbiológico. 6a edición. Editorial medica panamericana. España. 2008.

23. Popescu A, Doyle RJ. The Gram stain after more than a century. Biotech Histochem. 1996; 71: 145151.

24. Beveridge TJ. Mechanism of Gram variability in select bacteria. J Bacteriol. 1990; 172: 1609-1620.

25. Nagata K, Mino H, Yoshida S. Usefulness and limit of Gram staining smear examination. Rinsho Byori. 2010; 58: 490-497.

26. BROCK, Biología de los microrganismos. Madigan, M.T., Martinka, JM y Parker, J. 12a edición. Pearson Pretice Hall. 2009.

27. Razin S, Yogev D, Naot Y. Molecular biology and pathogenicity of mycoplasmas. Microbiol Mol Biol Rev. 1998; 62: 1094-1156. (Mycoplasmas)

28. Castro, AM. Bacteriología Médica basada en problemas. $2^{a}$ edición. Editorial manual moderno. 2014.

29. Martín-Sánchez Manuela, Martín-Sánchez María Teresa, Pinto Gabriel. Lugol reactive: History of Discovery and teaching applications. Educ. quím [revista en la Internet]. 2013 Ene [citado 2017 Abr 26] ; 24( 1 ): 31-36. Disponible en: http://www. scielo.org. $\mathrm{mx} / \mathrm{scielo}$.php?script $=$ sci_arttext $\&$ pi$\mathrm{d}=$ S0187-893X2013000100006\&lng=es.

30. Martín- Sánchez, M. Martín- Sánchez, MT. Pinto, G. Reactivo de Lugol: Historia de su descubrimiento y aplicaciones didácticas. Educ. quím. 24 (1), 31-36, 2013. Universidad Nacional Autónoma de México. Publicado en línea el 25 de noviembre de 2012, ISSNE 1870-8404

31. Luis SBM, Altava B. Introducción a la química orgánica. Universitat Jaume;1997.

32. Breakwell DP, Moyes RB, Reynolds J. Differential staining of bacteria: capsule stain. Curr Protoc Microbiol. 2009. Appendix 3: p. Appendix 3I.
33. Fung DC, Theriot JA. Imaging techniques in microbiology. Curr Opin Microbiol. 1998; 1: 346-351.

34. Corbett, D., Roberts, I.S. Capsular polysaccharides in Escherichia coli. Adv Appl Microbiol 65: 1-26. 2008.

35. Atkins, J. Principios de Química. Los caminos del descubrimiento. $3^{a}$ edición. Editorial médica panamericana. 2006

36. Breakwell DP, Moyes RB, Reynolds J. Differential staining of bacteria: capsule stain. Curr Protoc Microbiol. 2009. Appendix 3: p. Appendix 3I.

37. Murray P. Manual of clinical microbiology. 9th ed. USA: American Society for Microbiology; 2007.

38. Montoya, H. Microbiología básica para área de la salud y afines. $2^{a}$ edición. Colección salud. Universidad de Antioquia. 2008.

39. Corrales, L. González, A. Ávila, S. Conceptos Básicos de Microbiología. Bogotá. Editorial Universidad Colegio Mayor de Cundinamarca. 2008.

40. 40. Gerard J., Introducción a la Microbiología, Novena Edición, 2007, P.69-72

41. Gamazo, C. Sánchez, S. Camacho, A. Microbiología basada en la experimentación. Editorial Elsevier. España. 2013.

42. Brown, T. Le May, H. Bursten, B. Burdge, J. Química la ciencia central. 9a edición. Editorial Pearson. 2004.

43. Petrucci, R. Herring, F. Madura, J. Bissonnette, C. Química General. Principios y aplicaciones modernas. $11^{a}$ edición. Editorial Pearson. 2017.

44. Cordero, P. Verdugo, L. Apuntes de Bioquímica Humana. Metabolismo Intermedio. Facultad de Ciencias Médicas. Universidad de Cuenca. Cuenca-Ecuador. 2006

45. Selvakumar $\mathrm{N}$ et al. Comparison of variants of carbolfuchsin solution in Ziehl-Neelsen for detection of acidfast bacilli. Int J Tuberc Lung Dis. 2005; 9: 226-229. 
46. Murray, R. Bioquímica de Harper. 13era edición. Editorial manual moderno. 1994.

47. Salud OPDL. Manual para el diagnóstico bacteriológico de la tuberculosis. Vol. 1. 2008.

48. Keller PJ. Imaging morphogenesis: technological advances and biological insights. Science. 2013; 340: 123-168.

49. Zinserling V, Agapov MM, Orlov AN. The informative value of various methods for identifying acidfast bacilli in relation to the degree of tuberculosis process activity. Arkh Patol. 2018;80(3):40-45.

50. Ostos Ortíz, O., Rosas Arango, S., \& González Devia, J. (2019). Aplicaciones biotecnológicas de los microorganismos. NOVA, 17(31), 129-163. Recuperado a partir de https://revistas.unicolmayor.edu. co/index.php/nova/article/view/950

51. Calvo GA, Esteban RFJ, Montuenga FL. Técnicas en histología y biología celular. 2nd ed. Madrid Spain: Elsevier; 2009. 